\title{
Revision of the types of species of Alloxysta described by Cameron and Fergusson (Hymenoptera: Figitidae: Charipinae) and deposited in the Natural History Museum (London), including a key to the fauna of Great Britain
}

\author{
Mar FERRER-SUAY ${ }^{1 *}$, Jesús SELFA², David G. NOTTON \& Juli PUJADE-VILLAR ${ }^{4}$ \\ ${ }^{1,4}$ Universitat de Barcelona, Facultat de Biologia, Departament de Biologia Animal. Avda. Diagonal \\ 645, 08028-Barcelona, Spain \\ *E-mail: mar.ferrer.suay@gmail.com (corresponding author) \\ ${ }^{4}$ E-mail: jpujade@ub.edu \\ ${ }^{2}$ Universitat de València, Facultat de Ciències Biològiques, Departament de Zoologia. Campus de \\ Burjassot-Paterna, Dr. Moliner 50, E-46100 Burjassot (València), Spain \\ E-mail: jesus.selfa@uv.es \\ ${ }^{3}$ Natural History Museum, Life Sciences Department, Terrestrial Invertebrates Division. Cromwell \\ Road, SW7 5BD, London, United Kingdom \\ E-mail: d.notton@nhm.ac.uk
}

${ }^{1}$ urn:Isid:zoobank.org:author:B7059757-51CD-45DD-A182-C64FA5EF63C8
${ }^{2}$ urn:1sid:zoobank.org:author:C01B4FA6-6C5C-4DDF-A114-2B06D8FE4D20
${ }^{3}$ urn:1sid:zoobank.org:author:2E452EF2-703C-47C0-8432-6AB9C05AC06A
${ }^{4}$ urn:1sid:zoobank.org:author:94C497E0-C6A1-48BD-819D-FE5A8036BECD

Abstract. Type material of the species of Alloxysta described by Cameron and Fergusson and deposited in the Natural History Museum of London has been revised. Seven species are considered valid: Alloxysta abdera Fergusson, 1986, A. basimacula (Cameron, 1886), A. crassa (Cameron, 1889), A. mullensis (Cameron, 1883), A. piceomaculata (Cameron, 1883), A. pleuralis (Cameron, 1879) and A. semiaperta Fergusson, 1986. A. basimacula, A. crassa, A. maculicollis (Cameron, 1886), A. perplexa (Cameron, 1889) and A. piceomaculata are here removed from synonymy with A. macrophadna (Hartig, 1841). A. ruficeps (Cameron, 1883) is removed from synonymy with A. victrix (Westwood, 1833). A. caledonica (Cameron, 1886) and A. perplexa are here synonymized with A. basimacula. A. maculicollis, A. ruficeps and A. ruficollis (Cameron, 1883) are here synonymized with $A$. castanea (Hartig, 1841). A. ancylocera (Cameron, 1886) was correctly synonymized with A. fuscicornis (Hartig, 1841), A. curvicornis (Cameron, 1883) was correctly synonymized with A. victrix and A. filicornis (Cameron, 1889) was correctly synonymized with A. macrophadna. Complete redescriptions and illustrations are given for valid species. A key for all the Alloxysta species found so far in Great Britain is given.

Keywords. Figitidae, Charipinae, Alloxysta, Cameron, Fergusson.

Ferrer-Suay M., Selfa J., Notton D.G. \& Pujade-Villar J. 2013. Revision of the types of species of Alloxysta described by Cameron and Fergusson (Hymenoptera: Figitidae: Charipinae) and deposited in the Natural History 
Museum (London), including a key to the fauna of Great Britain. European Journal of Taxonomy 53: 1-27. http:// dx.doi.org/10.5852/ejt.2013.53

\section{Introduction}

Charipinae are small parasitoid wasps which are hyperparasitic on aphids (Hemiptera: Aphidoidea) via Aphidiinae (Hymenoptera: Ichneumonoidea: Braconidae) and Aphelininae (Hymenoptera: Chalcidoidea: Aphelinidae) and also hyperparasitoids of psyllids (Hemiptera: Psylloidea) via Encyrtidae (Hymenoptera: Chalcidoidea). They are an important negative influence on the beneficial biological control of primary parasitoids, and so it is necessary to identify them to species level before undertaking any studies of the biological control process. The chaotic status of the taxonomy of Charipinae has led us to study all the type material belonging to this subfamily, especially Alloxysta, since it is the most numerous (111 valid species according to Ferrer-Suay et al. 2012a), diverse and widely distributed genus. This is because the original descriptions are often very simple, without the necessary diagnostic characters and without comparisons to similar species. The best way to solve the taxonomy of a group is by characterising species, and then assigning names to those species by studying the characteristics of the type. These specimens are deposited in several institutions distributed around the world, especially in Europe.

With this aim we studied the types of Peter Cameron and Nigel D.M. Fergusson deposited in the Natural History Museum, London. The type material of Alloxysta, housed in the following collections, has already been revised: the Carl G. Thomson and Johan W. Zetterstedt collections deposited at the Lund Museum of Zoology, Sweden (Ferrer-Suay et al. 2013), the Vladimir I. Belizin collection deposited at the Zoological Institute of the Russian Academy of Sciences, Saint Petersburg, Russia (Ferrer-Suay et al. 2012b), the Mihail A. Ionescu collection deposited at the "Grigore Antipa" National Museum of Natural History, Bucharest, Romania (Ferrer-Suay et al. 2012c), the Theodor Hartig collection deposited at the Zoologische Staatssammlung Museum, München, Germany (Ferrer-Suay et al. in press), the Wolter Hellén collection deposited at the Finnish Museum of Natural History, Helsinki, Finland (Ferrer-Suay et al. in prep.), the John Curtis collection deposited at the National Museum of Victoria, Melbourne, Australia (Ferrer-Suay et al. in press), and the Fred G. Andrews, William H. Ashmead and Charles F. Baker collections deposited at the United States National Museum of Natural History (Smithsonian Institution), Washington DC, USA and at the Canadian National Collection of Insects, Ottawa, Canada (Ferrer-Suay et al. in press).

Charipinae are very small wasps, with a smooth and shiny body and with little interspecific variability. The early species descriptions of Charipinae were very short, mainly focused on coloration or size, and leaving out important characters which are essential nowadays to identify species. The most important diagnostic features used to distinguish between species of Alloxysta are: i) proportions of flagellomeres; ii) size and shape of radial cell; iii) presence or absence of pronotal carinae; and iv) presence or absence of propodeal carinae, and if present, the shape of the carinae. We have focused on these characters to establish whether each nominal species is valid or a synonym of another species.

Cameron described 18 species within the subfamily Charipinae:

\section{9: Allotria pleuralis}

1883: Allotria curvicornis, A. mullensis, A. piceomaculata, A. ruficeps, A. ruficollis, A. salicis

1886: Allotria ancylocera, A. basimacula, A. caledonica, A. maculicollis

1888: Phaenoglyphis forticornis

1889: Allotria collina, A. crassa, A. dolichocera, A. filicornis, A. megaptera, A. perplexa 
Three of these species belong to Phaenoglyphis and 15 to Alloxysta, of which after this study only five are considered valid: Alloxysta basimacula (Cameron, 1886), A. crassa (Cameron, 1889), A. mullensis (Cameron, 1883), A. piceomaculata (Cameron, 1883), and A. pleuralis (Cameron, 1879).

The species described by Fergusson (1986), Alloxysta abdera and A. semiaperta, which are currently considered valid, were also examined in detail for this study.

All valid species have been redescribed and their important features illustrated. Redescriptions are needed because the original ones are inadequate as mentioned above.

\title{
Material and Methods
}

The type specimens were borrowed from The Natural History Museum, London (BMNH). They were studied using stereo microscopy and were photographed using a Zeiss Discovery V8 compound microscope with an attached INFINITYX-21C digital camera feeding image files to a notebook or desktop computer; the program DeltaPix View-Pro AZ was then used to merge an image series (typically representing 20 focal planes) into a single in-focus image. All photographed specimens belong to type material.

Morphological terms used follow Paretas-Martinez et al. (2007). Measurements and abbreviations include F1-F12, first and subsequent flagellomeres. The width of the forewing radial cell was measured from the margin of the wing to the edge of vein Rs. The transfacial line ratio was calculated by dividing the length of the transfacial line (measured from the inner margins of compound eyes, across the face through the antennal sockets) by the compound eye height. The malar space ratio was calculated by dividing the length of the lower part of the gena (from the mouthparts to the ventral margin of the compound eye) by the compound eye height. Females and males of each species have the same characters except where indicated in redescriptions.

The species are treated here in alphabetical order.

\section{Results}

\author{
Class Hexapoda Blainville, 1816 \\ Order Hymenoptera Linnaeus, 1758 \\ Suborder Apocrita Latreille, 1810 \\ Superfamily Cynipoidea Latreille, 1802 \\ Family Figitidae Thomson, 1862 \\ Subfamily Charipinae Dalla Torre \& Kieffer, 1910 \\ Genus Alloxysta Förster, 1869
}

Alloxysta abdera Fergusson, 1986

Fig. 1

Alloxysta abdera Fergusson, 1986: 10.

\section{Type material}

\section{Holotype}

J, with the following labels: "England: Lancs. woodland, Belmont, 25.ix.1981", "Holotype" (round label with red margins), “ $\widehat{O}$ ”, "Holotype of Alloxysta abdera det. N.D.M. Fergusson, 1984”, "B.M. Type Hym. 7.175". 


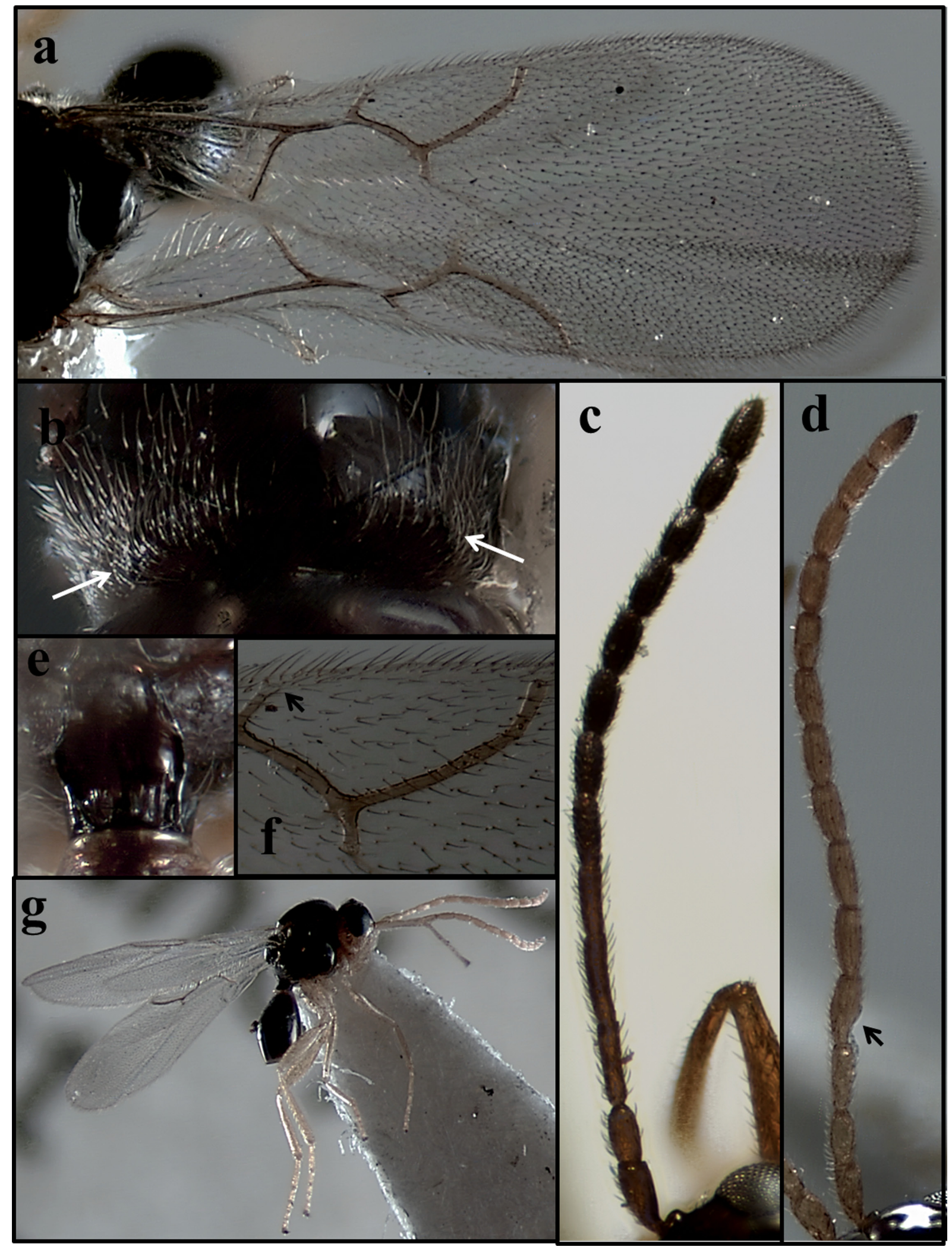

Fig. 1. Alloxysta abdera Fergusson, 1986. A. Fore wing. B. Pronotum (arrows indicate pronotal carinae). C. Antenna, $\rightarrow$. D. Antenna, $\widehat{O}$ (arrow shows curved F2). E. Propodeum. F. Fore wing radial cell (arrow indicates that the radial cell is completely open). G. Lateral habitus, $P$. 


\section{Paratype}

ㅇ, with the following labels: "England: Lancs., woodland, Belmont, 25.ix.1981", "Alloxystinae" (handwritten), "Paratype" (round label with yellow margins), "A. abdera det. N.D.M. Fergusson".

\section{Redescription}

Coloration. Head yellowish brown, mesosoma and metasoma very dark brown. Antennae dark yellow. Legs yellow and veins yellowish brown.

HEAD. Transversely ovate, smooth and shiny, wider than high in front view; with setae below, between and a few above toruli. With few setae on vertex and with many setae on face. Transfacial line $1.0 \mathrm{x}$ height of compound eye. Malar space $0.6 \mathrm{x}$ height of compound eye.

ANTENNA. Female: 13-segmented, filiform. All antennomeres covered with sparse setae. F1-F3 thinner and smoother than remaining flagellomeres; F4-F11 club-shaped, with rhinaria. Pedicel $1.9 \mathrm{x}$ as long as wide; F1 $4.1 \mathrm{x}$ as long as wide; F2 $3.8 \mathrm{x}$ as long as wide; F3 $3.3 \mathrm{x}$ as long as wide; F4 $2.5 \mathrm{x}$ as long as wide. F1 $1.4 \mathrm{x}$ as long as pedicel; F1 subequal to F2; F2 1.2 $\mathrm{x}$ as long as F3; F3 $1.1 \mathrm{x}$ as long as F4; F4-F11 subequal in length, width and shape (Fig. 1C). Male: 14-segmented, filiform. All antennomeres covered with sparse setae. F1 thinner and smoother than remaining flagellomeres; F2-F12 club-shaped, with rhinaria. Pedicel $2.0 \mathrm{x}$ as long as wide; F1 $3.2 \mathrm{x}$ as long as wide; F2 $2.1 \mathrm{x}$ as long as wide; F3 $2.6 \mathrm{x}$ as long as wide; F4 $2.4 \mathrm{x}$ as long as wide. F2 curved. F1 $1.2 \mathrm{x}$ as long as pedicel; F1 $1.1 \mathrm{x}$ as long as F2; F3 1.1 $\mathrm{x}$ as long as F2; F3-F12 subequal in length, width and shape (Fig. 1D).

Mesosoma. Pronotum covered with abundant setae, less setae on anterior margin, with two thick carinae clearly visible under the pubescence (Fig. 1B). Mesoscutum smooth and shiny, round in dorsal view with scattered setae. Scutellum also smooth and shiny with few scattered setae, being abundant on apex. Height of mesopleural triangle along anterior margin $1.6 \mathrm{x}$ the height of mesopleuron. Propodeum entirely covered by setae, with two carinae forming a thick plate, with setae on top and sides slightly curved (Fig. 1E).

FORE WING. Longer than body, $1.4 \mathrm{x}$ as long as mesosoma and metasoma together in both male and female (Fig. 1A). Covered with dense pubescence; marginal setae present. Completely open radial cell, $2.2 \mathrm{x}$ as long as wide in both male and female. R1 short and curved; Rs long and curved. R1 and Rs not reaching costal margin (Fig. 1F).

Metasoma. Anterior part with an incomplete ring of setae, glabrous at centre, wider laterally. Metasoma smooth and shiny, T3 and T4 clearly distinguished.

\section{Remarks}

According to the original description, Alloxysta abdera is represented by 9 specimens $(6 \widehat{\delta} \widehat{\delta}$ and 3 우) in BMNH. One male was designated as holotype by Fergusson and the rest of the specimens as paratypes; we have examined only the holotype $\left(\delta^{\Uparrow}\right)$ and one paratype $(+$ ). This species is very similar to A. pallidicornis (Curtis, 1838) because both species have a completely open radial cell, pronotal and propodeal carinae present, and flagellomeres club-shaped and with rhinaria from F2, but they differ in the ratios between F2 and F3. F3 is slightly longer than F2 in A. abdera (Fig. 1C), whereas in $A$. pallidicornis $\mathrm{F} 2$ is longer than F3; size of radial cell: $2.2 \mathrm{x}$ as long as wide in A. abdera (Fig. 1F) but 2.6 $\mathrm{x}$ as long as wide in A. pallidicornis; shape of propodeal carinae: with two carinae forming a thick plate, with setae on top and sides slightly curved in A. abdera (Fig. 1E) but with two carinae well defined and separated by setae in the first half and forming a plate in the last half in A. pallidicornis. 


\section{Alloxysta basimacula (Cameron, 1886) stat. rev.}

Fig. 2

Allotria basimacula Cameron, 1886: 87.

Allotria caledonica Cameron, 1886: 88 . New synonymy

Allotria perplexa Cameron, 1889: 58. New synonymy

Dilyta basimacula - Kieffer 1900: 114.

Dilyta caledonica - Kieffer 1900: 114.

Dilyta perplexa - Kieffer 1900: 114.

Alloxysta (Alloxysta) basimacula - Dalla Torre \& Kieffer 1902: 38.

Alloxysta (Alloxysta) caledonica - Dalla Torre \& Kieffer 1902: 38.

Alloxysta (Alloxysta) perplexa - Dalla Torre \& Kieffer 1902: 39.

Alloxysta perplexa - Hellén 1931: 4.

Alloxysta basimacula - Andrews 1978: 78.

Alloxysta caledonica - Andrews 1978: 78.

\section{Type material}

\section{Lectotype of Allotria basimacula}

, designated by Quinlan (1974: 6), with the following labels: "Lectotype" (round label with blue margin), "Mugdock, Glasgow, Scotland, basimacula" (handwritten), "Cameron 96 76. Mugdoch", "Lectotype 9 Allotria basimacula C. det. J. Quinlan, 1973" (handwritten), "B.M. TYPE HYM. 7.120.", "Alloxysta basimacula (Cameron, 1886) det. M. Ferrer-Suay 2012".

\section{Holotype of Allotria caledonica}

, with the following labels: "Holotype" (round label with red margins), "Cameron 96 76. Mugdock, Glasgow, Scotland", "caledonica Cam." (handwritten), "Holotype 9 Allotria caledonica Cameron det. J. Quinlan, 1973”, "B.M. TYPE HYM. 7.126”, “Alloxysta basimacula (Cameron, 1886) det. M. FerrerSuay $2012 "$.

\section{Lectotype of Allotria perplexa}

, designated by Quinlan (1978: 125), with the following labels: "Lectotype" (round label with blue margins), [illegible], "Cameron 96-76, South Bank, River Clyde, Scotland", "Lectotype of Allotria perplexa Cam. ㅇ, det. J. Quinlan, 1977”, “Alloxysta det. J. Quinlan”, "B.M. Type Hym. 7.170", "Alloxysta basimacula (Cameron, 1886) + det. M. Ferrer-Suay 2012".

\section{Redescription}

Coloration. Head yellowish brown, mesosoma and metasoma brown. Scape, pedicel and F1-F3 dark yellow; F4-F11 brown. Legs dark yellow and veins yellowish brown.

HEAD. Transversely ovate, smooth and shiny, wider than height in front view; with setae below, between and a few above toruli. With few scattered setae on vertex and with many setae on face. Transfacial line $1.1 \mathrm{x}$ height of compound eye. Malar space $0.4 \mathrm{x}$ height of compound eye.

AnTENNA. Female: 13-segmented, filiform. All antennomeres covered with sparse setae. F1-F3 thinner and smoother than remaining flagellomeres; F4-F11 club-shaped, with rhinaria. Pedicel $1.6 \mathrm{x}$ as long as wide; F1 $3.6 \mathrm{x}$ as long as wide; F2 $3.6 \mathrm{x}$ as long as wide; F3 $2.9 \mathrm{x}$ as long as wide; F4 $2.7 \mathrm{x}$ as long as wide. F1 $1.3 \mathrm{x}$ as long as pedicel; F1 subequal to F2; F2 $1.2 \mathrm{x}$ as long as F3; F4 $1.2 \mathrm{x}$ as long as F3; F4-F11 subequal in length, width and shape (Fig. 2D). 
Mesosoma. Pronotum covered by abundant setae, less at central area and distolateral margins; with two long, thick, clearly visible carinae (Fig. 2C). Mesoscutum smooth and shiny, round in dorsal view, with scattered setae. Scutellum also smooth and shiny, with few scattered setae, abundant on apex of scutellum. Height of mesopleural triangle along anterior margin $0.7 \mathrm{x}$ height of mesopleuron. Propodeum covered by abundant setae, without carinae (Fig. 2E).

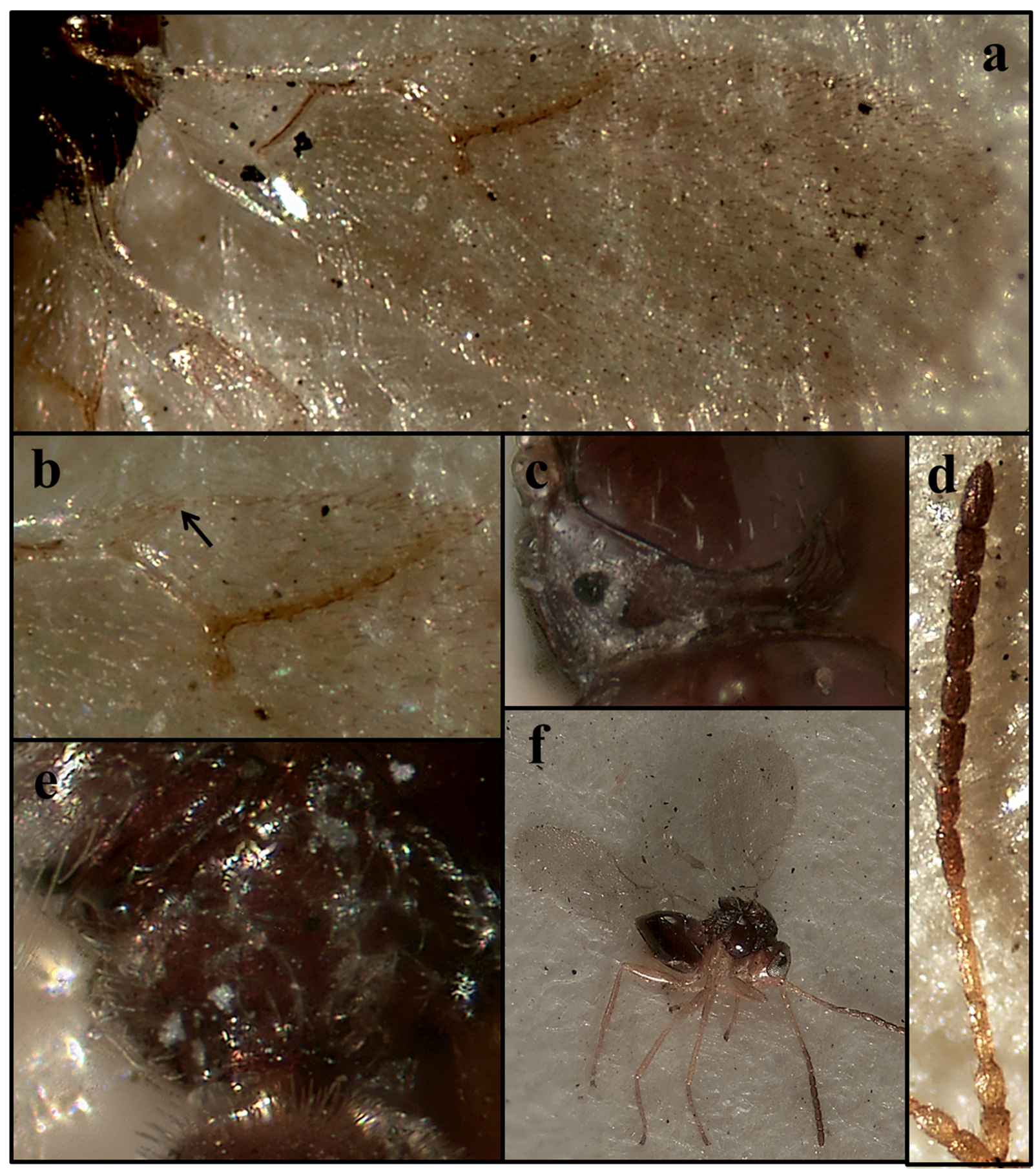

Fig. 2. Alloxysta basimacula (Cameron, 1886). A. Fore wing. B. Fore wing radial cell (arrow indicates that the radial cell is completely open). C. Pronotum. D. Antenna, $\uparrow$. E. Propodeum. F. Lateral habitus,, . 
Fore WING. Longer than body, $1.6 \mathrm{x}$ as long as mesosoma and metasoma together (Fig. 2A). Covered with dense pubescence; marginal setae present. Completely open radial cell, $3.0 \mathrm{x}$ as long as wide. R1 short and straight; Rs long and slightly curved (Fig. 2B).

Metasoma. Anterior part with an incomplete ring of setae, glabrous at centre, widened laterally. Metasoma smooth and shiny, T3 and T4 clearly distinguished.

\section{Remarks}

Alloxysta basimacula was synonymized with A. macrophadna (Hartig, 1841) by Fergusson (1986). After studying the type material, it is here considered as a different and valid species. The type series of this species consists of the lectotype female and one paralectotype male. Only the lectotype has been studied here.

Alloxysta caledonica was synonymized with A. macrophadna (Hartig, 1841) by Fergusson (1986). It is represented in BMNH only by the holotype female. After studying the holotype of $A$. caledonica, it was found to be the same species as $A$. basimacula, so these two species are synonymized here.

Alloxysta perplexa was also synonymized by Fergusson (1986) with A. macrophadna (Hartig, 1841). A. perplexa is represented in BMNH by the lectotype female and ten paralectotypes $(8 \widehat{\delta} \delta$ and 2 우). Comments on the type series of A. perplexa were given by Quinlan (1978: 125). However, after comparing the lectotype of $A$. perplexa with $A$. macrophadna, we found that they can be differentiated by the shape of the radial cell, completely open in A. perplexa and partially open in A. macrophadna. The main features of $A$. perplexa are coincident with those of $A$. basimacula; for this reason we establish here this new synonymy.

Alloxysta castanea (Hartig, 1841)

Xystus castaneus Hartig, 1841: 352.

Allotria ruficeps Cameron, 1883: 365 . New synonymy

Allotria ruficollis Cameron, 1883: 365 . New synonymy

Allotria maculicollis Cameron, 1886: 87 . New synonymy

Allotria megaptera Cameron, 1889: 54 (synonymized with Alloxysta ruficollis in Ferrer-Suay et al. 2012a).

Charips (Charips) cameroni Dalla Torre \& Kieffer, 1910: 283 (new name for Allotria ruficeps Cameron, 1883; non Allotria ruficeps Zetterstedt, 1838).

Dilyta maculicollis - Kieffer 1900: 114.

Alloxysta (Alloxysta) maculicollis - Dalla Torre \& Kieffer 1902: 38.

Allotria (Allotria) ruficollis - Dalla Torre \& Kieffer 1902: 41.

Charips (Charips) ruficollis - Dalla Torre \& Kieffer 1910: 280.

Alloxysta maculicollis - Andrews 1978: 85.

Alloxysta ruficollis - Andrews 1978: 90.

Alloxysta cameroni - Quinlan 1978: 126.

\section{Type material}

\section{Holotype of Allotria ruficeps}

+ , with the following labels: "Holotype" (round label with red margins), "Cameron 96-76 Galloway", "Galloway ruficeps" (handwritten), "ruficeps Cam." (handwritten), "Allotria ruficeps Cameron Q" (handwritten, red label), "Holotype of Allotria ruficeps Cam. §ै det. J. Quinlan, 1977”, “A. cameroni det. N.D.M. Fergusson, 1984”, “B.M. Type Hym. 7.176”, “Alloxysta castanea (Hartig, 1841) o det. M. Ferrer-Suay 2012". 


\section{Lectotype of Allotria ruficollis}

+ , designated here with the following labels: "Holotype" (round label with red margin), "Mull, ruficollis" (handwritten), "Cameron 96-76, Mull" (in front), "ruficollis" (behind), "ruficollis Cam" (handwritten), "Holotype + Allotria ruficollis, Cameron det. J. Quinlan, 1973", "B.M. Type Hym. 7.123", "N.B. Quinlan, 1974 assumed this is a holotype, however Cameron made no designation and there is no clear evidence of monotypy, hence Rec. 73F applies: i.e. it is a SYNTYPE", "Lectotype Allotria ruficollis ㅇ Cameron, 1883 design. M. Ferrer-Suay 2012” (red label), “Alloxysta castanea (Hartig, 1841) 으, M. Ferrer-Suay det. 2012" (white label).

\section{Holotype of Allotria maculicollis}

+ , with the following labels: "Holotype" (round label with red margins), "maculicollis" (handwritten), "Cameron 96 76, Galloway", "Galloway maculicollis Cam” (handwritten), “Alloxysta fulviceps Curt. ㅇ, G.J. Kerrich det. 1948, compared with type", "Allotria maculicollis" (handwritten, red label), "Holotype Allotria maculicollis Cam. + det. J. Quinlan, 1977”, "B.M. Type Hym. 7.171”, “Alloxysta castanea (Hartig, 1841) + det. M. Ferrer-Suay 2012".

\section{Remarks}

Alloxysta maculicollis was synonymized with A. macrophadna (Hartig, 1841) by Fergusson (1986). Alloxysta maculicollis is represented in BMNH by the lectotype female. According to Quinlan (1978: 125), there are other specimens in the BMNH collection with a handwritten name "maculicollis" on the reverse side which are not considered to be syntypic. After studying the A. maculicollis type material it was found that it is different from A. macrophadna, mainly because the propodeal carinae are present forming a plate, which is not the case for A. macrophadna. Alloxysta maculicollis agrees with A. castanea in all significant characters, so they are synonymized here.

Alloxysta ruficeps was synonymized by Fergusson (1986) with A. fulviceps (Curtis, 1838). According to Pujade-Villar et al. (2011), A. fulviceps (Curtis) is a synonym of A. victrix (Westwood, 1833). Alloxysta ruficeps is represented in BMNH only by the holotype male. After studying this specimen, we found that it is the same species as $A$. castanea, because they both have: partially open radial cell, pronotal carinae present and propodeal carinae forming a plate, and the same proportion between flagellomeres. For these reasons, we here synonymize $A$. ruficeps with $A$. castanea.

Alloxysta ruficollis is represented in BMNH by only one specimen (female). It was considered to be the holotype by Quinlan (1974: 9), but according to the last label added to this specimen, it cannot be the holotype because Cameron did not designate a holotype and there is no evidence that the species was based on only one specimen (monotypy). Moreover, the original description was based on a male (although it is possible that Cameron misinterpreted the sex). For these reasons, this specimen is considered as a syntype and we here designate it as the lectotype. Alloxysta ruficollis was synonymized by Quinlan with Alloxysta erythrothorax (Hartig, 1840) and later Evenhuis (1972) synonymized it with A. castanea. Van Veen (pers. com.) considered A. ruficollis to be a valid species, with A. megaptera (Cameron, 1889) as its synonym (Ferrer-Suay et al. 2012a). After comparing this species with other Alloxysta, we conclude that Evenhuis was correct.

Alloxysta crassa (Cameron, 1889) stat. rev.

Fig. 3

Allotria crassa Cameron, 1889: 59.

Dilyta crassa - Kieffer 1900: 114.

Alloxysta (Alloxysta) crassa - Dalla Torre \& Kieffer 1902: 38.

Alloxysta crassa - Hellén 1963: 12. 


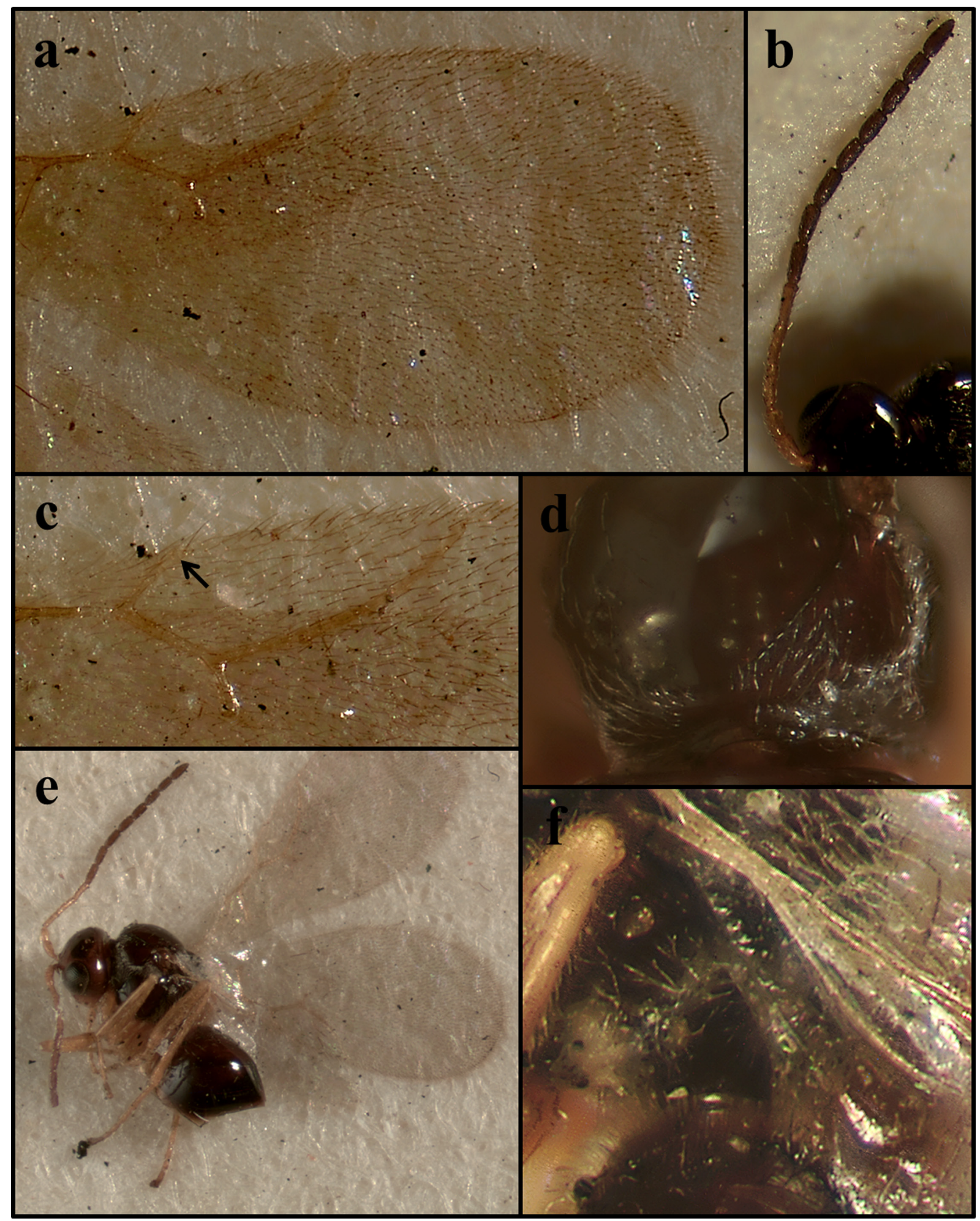

Fig. 3. Alloxysta crassa (Cameron, 1889). A. Fore wing. B. Antenna, ․ C. Fore wing radial cell (arrow illustrates that the radial cell is completely open). D. Pronotum. E. Lateral habitus, + . F. Propodeum. 


\section{Type material}

\section{Lectotype}

+, designated by Quinlan (1974: 7), with the following labels: "Lectotype" (round label with blue margins), "Bonar" (handwritten), "crassa Cam" (handwritten), "Cameron 96 76, Bonar Bridge, Sutherland, Scotland", "Lectotype of Allotria crassa Cam. o det. J. Quinlan, 1973", "B.M. Type Hym. 7.128”, “Alloxysta crassa (Cameron, 1889) + det. M. Ferrer-Suay 2012”.

\section{Redescription}

Coloration. Head yellowish brown, mesosoma and metasoma brown. Scape, pedicel and F1-F3 dark yellow; F4-F11 brown. Legs dark yellow and veins yellowish brown.

HeAD. Transversely ovate, smooth and shiny, wider than high in front view. With setae below, between and a few above toruli. With few scattered setae on vertex and with many setae on face. Transfacial line $1.2 \mathrm{x}$ height of compound eye. Malar space $0.5 \mathrm{x}$ height of compound eye.

AntenNA. Female: 13-segmented, filiform. All antennomeres covered with sparse setae. F1-F3 thinner and smoother than remaining flagellomeres; F4-F11 club-shaped, with rhinaria. Pedicel $1.7 \mathrm{x}$ as long as wide; F1 $3.3 \mathrm{x}$ as long as wide; F2 $3.6 \mathrm{x}$ as long as wide; F3 $3.6 \mathrm{x}$ as long as wide; F4 $3.0 \mathrm{x}$ as long as wide. F1 $1.7 \mathrm{x}$ as long as pedicel; F1 $1.2 \mathrm{x}$ as long as F2; F2-F11 subequal in length, width and shape (Fig. 3B). Male unknown.

Mesosoma. Pronotum covered by abundant setae, less at distolateral margins; with two thick, clearly visible carinae (Fig. 3D). Mesoscutum smooth and shiny, round in dorsal view, with scattered setae. Scutellum also smooth and shiny, with few scattered setae, abundant on apex of scutellum. Height of mesopleural triangle along anterior margin $0.9 \mathrm{x}$ height of mesopleuron. Propodeum covered by abundant setae, propodeal carinae absent (Fig. 3F).

ForE WING. Longer than body, $1.5 \mathrm{x}$ as long as mesosoma and metasoma together (Fig. 3A). Covered with dense pubescence; marginal setae present. Completely open radial cell, $2.8 \mathrm{x}$ as long as wide. R1 short and straight; Rs long and slightly curved (Fig. 3C).

Metasoma. Anterior part with an incomplete ring of setae, glabrous at centre, wider laterally. Metasoma smooth and shiny, T3 and T4 clearly distinguished.

\section{Remarks}

This species was synonymized by Fergusson (1986) with A. macrophadna (Hartig, 1841). Alloxysta crassa is represented in BMNH by the lectotype female and 3 paralectotype females. Comments on the type series of A. crassa are presented in Quinlan (1974: 7). However, after revising the lectotype we found that it is a different and valid species. Alloxysta crassa can be differentiated from A. macrophadna by the shape of the radial cell: completely open in A. crassa (Fig. 3C) while partially open in A. macrophadna; relation between flagellomeres: F2 longer than F1 and F3 in A. crassa (Fig. 3B), whereas F2 is subequal to F1 and slightly longer than F3 in A. macrophadna.

\section{Alloxysta fuscicornis (Hartig, 1841)}

Xystus fuscicornis Hartig, 1841: 352.

Allotria ancylocera Cameron, 1886: 85 (synonymized in Evenhuis 1982: 23).

Allotria (Allotria) ancylocera - Dalla Torre \& Kieffer 1902: 40.

Charips ancylocera - Hafez 1961: 85.

Alloxysta ancylocera - Andrews 1978: 77. 


\section{Type material}

\section{Holotype of Allotria ancylocera}

$\widehat{0}$, with the following labels: "Holotype" (round label with red margins), "ancylocera" (handwritten),

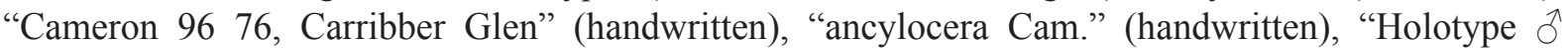
Allotria ancylocera Cam. det. J. Quinlan 1973" (handwritten), "B.M. TYPE HYM. 7.119.”, “Alloxysta fuscicornis (Hartig, 1841) det. M. Ferrer-Suay 2012".

\section{Remarks}

Allotria ancylocera was synonymized with Alloxysta fuscicornis (Hartig, 1841) by Evenhuis (1982: 23). Its type material has been revised and the validity of this synonymy is confirmed here.

Alloxysta macrophadna (Hartig, 1841)

Xystus macrophadnus Hartig, 1841: 352.

Allotria filicornis Cameron, 1889: 57 (synonymized in Fergusson 1986: 10).

\section{Type material}

\section{Lectotype of Allotria filicornis}

O, designated by Quinlan (1978: 125) with the following labels: "Holotype" (round label with red margins), "Cladish" (handwritten), "Cameron 9676 Cladish", "filicornis Cam" (handwritten), "Holotype of Allotria filicornis Cam. Ò det. J. Quinlan, 1977”, “B.M. Type Hym. 7.169”, “Alloxysta macrophadna (Hartig, 1841) § det. Ferrer-Suay, 2012” (white label).

\section{Remarks}

Alloxysta filicornis is represented by the holotype male and five paralectotype males at BMNH. According to Quinlan's notes (1978: 125), there is another conspecific male from England, but it is not considered a paralectotype, because the Cameron's original description stated that the specimens were collected only in Scotland. This species was synonymized by Fergusson (1986) with A. macrophadna (Hartig, 1841) and the validity of this synonymy is confirmed here.

\section{Alloxysta mullensis (Cameron, 1883)}

Fig. 4

Allotria mullensis Cameron, 1883: 366.

Allotria (Allotria) mullensis - Dalla Torre \& Kieffer 1902: 40.

Charips (Charips) mullensis - Dalla Torre \& Kieffer 1910: 284.

Alloxysta mullensis - Quinlan 1974: 8.

\section{Type material}

\section{Lectotype}

, with the following labels: "Holotype" (round label with red in the margin), "mullensis" (handwritten), "mullensis Cam" (handwritten), "Cameron. 96-76., Mull", "mullensis" (under label), "Holotype $q$ of Allotria mullensis Cameron. det. J. Quinlan, 1973" (white label), "B. M. TYPE HYM. 7.125" (white label), "Lectotype Allotria mullensis + Cameron, 1883 design. Ferrer-Suay \& J.P-V 2011" (red label), “Alloxysta mullensis (Cameron, 1883) ㅇ, Ferrer-Suay \& J.P-V det." (white label).

\section{Redescription}

Coloration. Head brown, mesosoma and metasoma dark brown. Pedicel, scape and F1-F3 dark yellow; F4-F11 yellowish brown. Legs and veins yellow. 


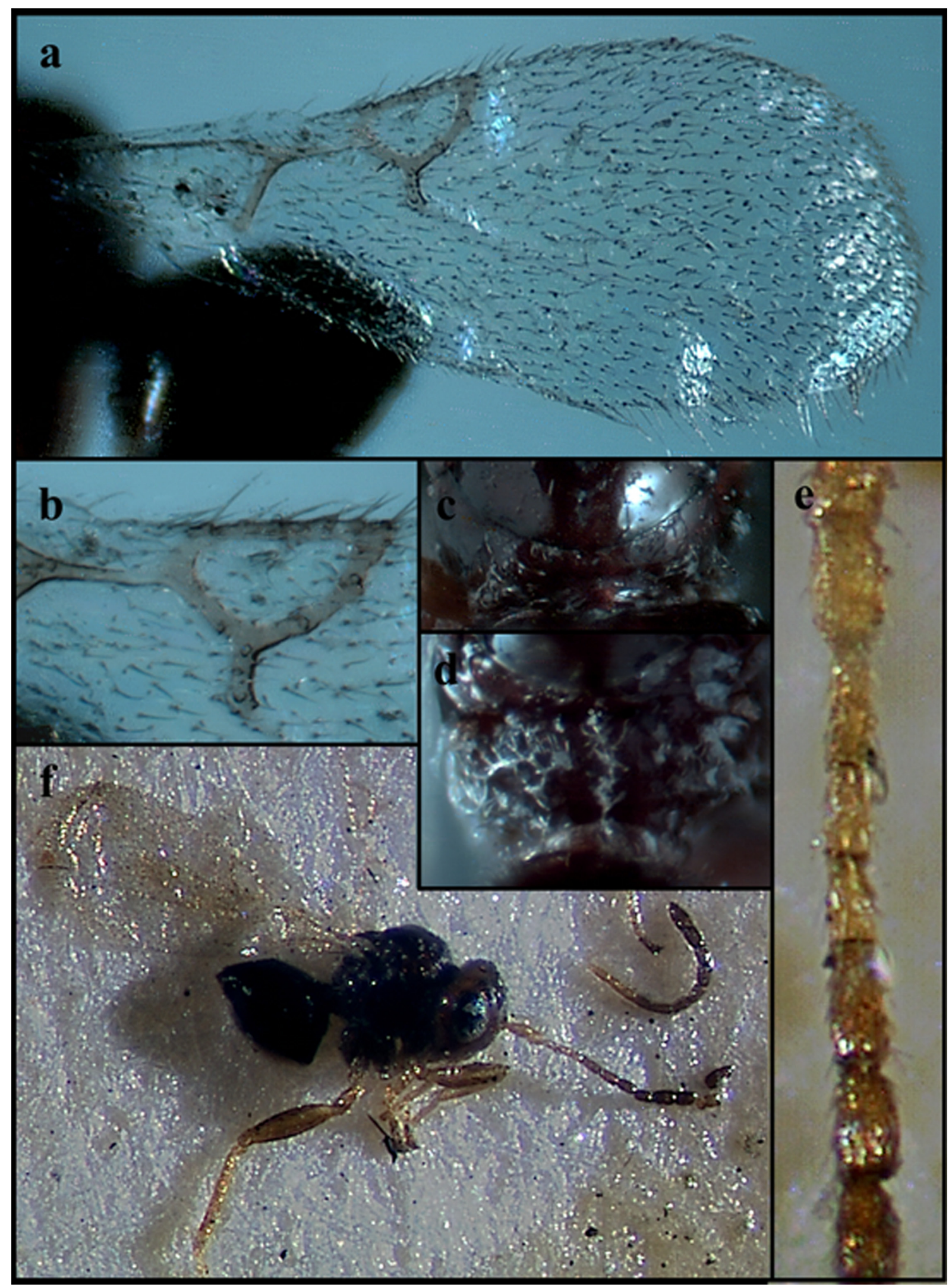

Fig. 4. Alloxysta mullensis (Cameron, 1883). A. Fore wing. B. Fore wing radial cell. C. Pronotum. D. Propodeum. E. Antenna, $q$. F. Lateral habitus,, . 
HEAD. Transversely ovate, smooth and shiny, wider than high in front view. With setae present below and between toruli. Without setae on vertex and with a lot of setae on frons. Transfacial line $1.3 \mathrm{x}$ the height of compound eye. Malar space $0.5 \mathrm{x}$ the height of compound eye.

ANTENNA. Female: 13-segmented, filiform. All antennomeres covered with sparse setae. F1-F3 smoother and thinner than remaining ones; F4-F11 club-shaped, with rhinaria. Pedicel $1.8 \mathrm{x}$ as long as wide; F1 $3.2 \mathrm{x}$ as long as wide; F2 $2.1 \mathrm{x}$ as long as wide; F3 $2.0 \mathrm{x}$ as long as wide; F4 $2.1 \mathrm{x}$ as long as wide. Pedicel subequal to F1; F1 1.4 $\mathrm{x}$ as long as F2; F2 subequal to F3; F4 $1.4 \mathrm{x}$ as long as F3; F4-F11 subequal in length, width and shape (Fig. 4E). Male: as female, without any curved flagellomeres.

Mesosoma. Pronotum covered by sparse setae except a small area of the center, few setae on distolateral corners; without carinae (Fig. 4C). Mesoscutum smooth and shiny, round in dorsal view with few scattered setae. Scutellum also smooth and shiny, also with sparse setae. Height of mesopleural triangle along anterior margin more or less $1.3 \mathrm{x}$ height of mesopleuron. Propodeum covered by abundant pubescence; two wide propodeal carinae separated by few setae on top and forming a plate on bottom; sides sub-parallel anteriorly and very slightly curved posteriorly (Fig. 4D).

ForE WING. Longer than body, $1.5 \mathrm{x}$ as long as mesosoma and metasoma together. Forewing covered by abundant pubescence; marginal setae present (Fig. 4A). Radial cell closed, $2.2 \mathrm{x}$ as long as wide (Fig. 4B). R1 short and straight; Rs longer than R1 and curved.

Metasoma. Proximal part with an incomplete ring of setae, setae absent in the center and present laterally. Remainder of metasoma smooth and shiny, with terga clearly visible.

\section{Remarks}

The type series of Alloxysta mullensis is represented by one specimen in BMNH. It was designated as the lectotype in Ferrer-Suay et al. (2012d). This species was synonymized with A. brevis (Thomson, 1862 ) by Fergusson (1986) as were $A$. arcuata (Kieffer, 1902) and $A$. castaneiceps (Kieffer, 1904). This "brevis group" is represented by very small specimens, with small closed radial cells, small flagellomeres very similar to each other and a propodeal plate in the center of the propodeum. The "brevis group" has been tackled in a previous study (Ferrer-Suay et al. 2012d), who concluded that A. mullensis should be considered a valid species. Alloxysta mullensis differs from A. brevis in the proportion of antennomeres: $\mathrm{F} 1$ subequal to pedicel in $A$. mullensis but shorter than pedicel in $A$. brevis, and $\mathrm{F} 1$ longer than $\mathrm{F} 2$ in $A$. mullensis while subequal to $\mathrm{F} 2$ in $A$. brevis. Furthermore, $A$. mullensis differs from $A$. arcuata in lacking pronotal carinae, which are present in A. arcuata.

\section{Alloxysta piceomaculata (Cameron, 1883) stat. rev.}

Fig. 5

Allotria piceomaculata Cameron, 1883: 367.

Dilyta piceomaculata - Kieffer 1900: 114.

Alloxysta (Alloxysta) piceomaculata - Dalla Torre \& Kieffer 1902: 39.

Alloxysta piceomaculata - Hellén 1963: 13.

\section{Type material}

\section{Holotype}

, with the following labels: "Holotype" (round label with red margin), "Cameron 96-76. Dumfries", "Dumfries, piceomaculata" (handwritten), "piceomaculata Cam" (handwritten), "Holotype $q$ Allotria piceomaculata C. det. J. Quinlan, 1973" (handwritten), "B.M. TYPE HYM. 7.127”, “Alloxysta piceomaculata (Cameron, 1883) det. M. Ferrer-Suay 2012". 


\section{Redescription}

Coloration. Head, mesosoma and metasoma yellowish brown. Scape, pedicel and F1-F2 dark yellow; F3-F11 brown. Legs and veins dark yellow.

HEAD. Transversely ovate, smooth and shiny, wider than high in front view. With setae below and between toruli and a few setae above toruli. With few scattered setae on vertex and with many setae on face. Transfacial line and malar space cannot be measured due to the position of the type specimen.

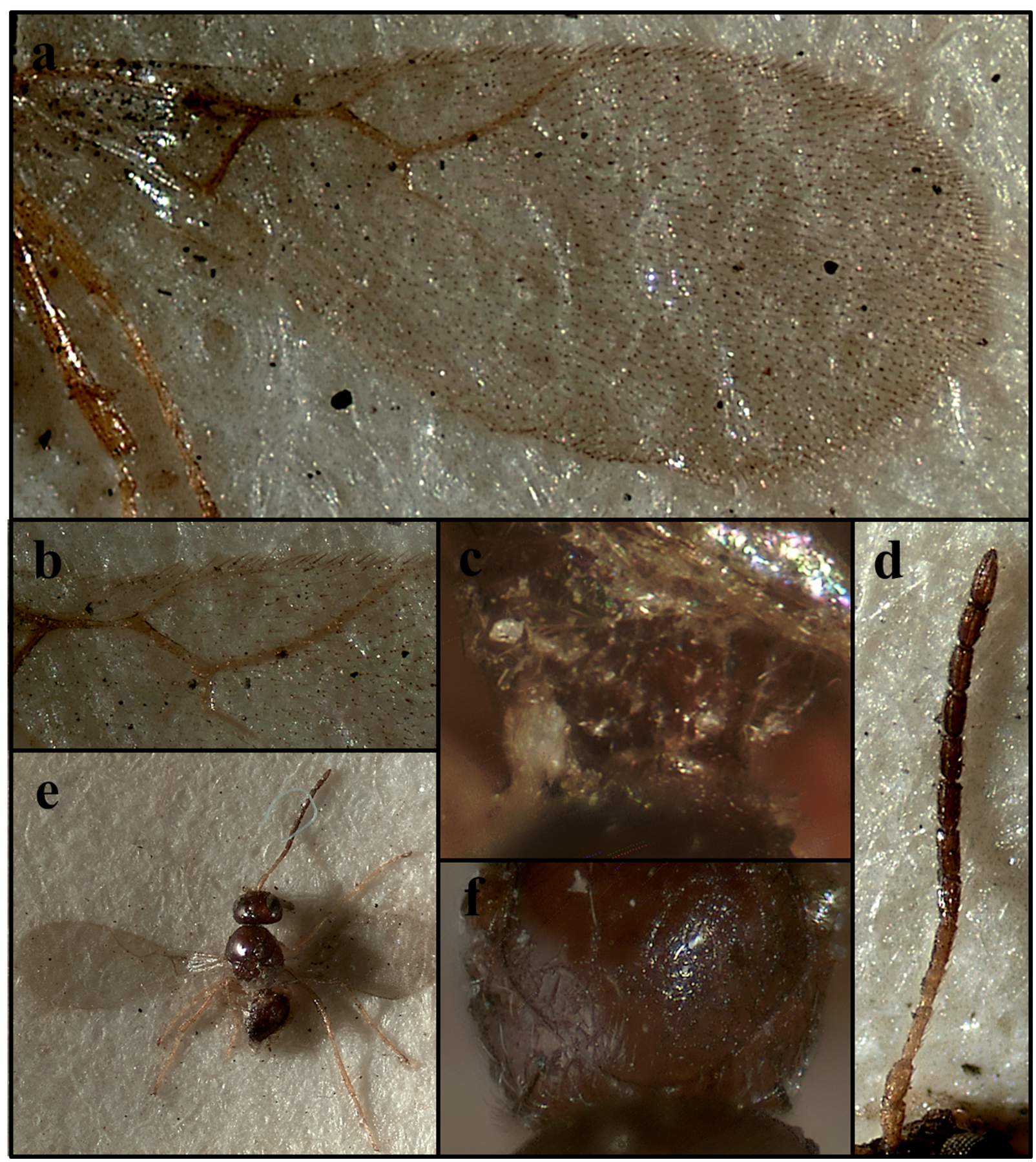

Fig. 5. Alloxysta piceomaculata (Cameron, 1883). A. Fore wing. B. Fore wing radial cell. C. Propodeum. D. Antenna, $q$. E. Lateral habitus, $q$. F. Pronotum. 
Antenna. Female: 13-segmented, filiform. All antennomeres covered with sparse setae. F1-F3 thinner and smoother than remaining flagellomeres; F4-F11 club-shaped, with rhinaria. Pedicel $1.9 \mathrm{x}$ as long as wide; F1 $1.4 \mathrm{x}$ as long as wide; F2 $2.4 \mathrm{x}$ as long as wide; F3 $2.6 \mathrm{x}$ as long as wide; F4 $2.1 \mathrm{x}$ as long as wide. F1 $1.2 \mathrm{x}$ as long as pedicel; F1 $1.4 \mathrm{x}$ as long as F2; F3 1.1 $\mathrm{x}$ as long as F2; F3 subequal to F4; F4-F11 subequal in length, width and shape (Fig. 5D). Male unknown.

Mesosoma. Pronotum covered by abundant setae, with two long and thick, clearly visible carinae (Fig. 5F). Mesoscutum smooth and shiny, round in dorsal view, with scattered setae. Scutellum also smooth and shiny, with few scattered setae, abundant on apex of scutellum. Height of mesopleural triangle along anterior margin $1.3 \mathrm{x}$ height of mesopleuron. Propodeum covered by abundant setae, propodeal carinae absent (Fig. 5C).

ForE WING. Longer than body, $1.8 \mathrm{x}$ as long as mesosoma and metasoma together (Fig. 5A), covered with dense pubescence; marginal setae present. Open radial cell, $2.8 \mathrm{x}$ as long as wide. R1 short and straight; Rs long and slightly curved (Fig. 5B).

Metasoma. Anterior part with an incomplete ring of setae, glabrous at centre, wider laterally. Metasoma smooth and shiny, T3 and T4 clearly distinguished.

\section{Remarks}

The type series of Alloxysta piceomaculata is represented by the lectotype female and one paralectotype male. This species was synonymized with A. macrophadna (Hartig, 1841) by Fergusson (1986). After studying the type material, we found it was different from A. macrophadna and therefore it is here considered a valid species. This species is similar to Alloxysta nigrita (Thomson, 1862) in having a completely open radial cell, pronotal carinae present, propodeal carinae absent, and flagellomeres club-shaped and with rhinaria from F4. However, they can be differentiated by the relative length/width of F1: $1.4 \mathrm{x}$ as long as wide in A. piceomaculata, but $4.4 \mathrm{x}$ in A. nigrita; ratio between the lengths of F3 and F4: F3 subequal to F4 in A. piceomaculata but longer than F4 in A. nigrita.

Alloxysta pleuralis (Cameron, 1879)

Fig. 6

Allotria pleuralis Cameron, 1879: 113.

Allotria (Allotria) pleuralis - Dalla Torre \& Kieffer 1902: 40.

Charips (Charips) pleuralis - Dalla Torre \& Kieffer 1910: 279.

Alloxysta pleuralis - Andrews 1978: 88.

\section{Material examined}

\section{Lectotype}

9, designated by Quinlan (1974: 8), with the following labels: "8", "Cameron 96-76" (in front), "pleuralis" (behind, handwritten), "Lectotype" (round label with blue margins), "Lectotype $q$ Allotria pleuralis Cameron det. J. Quinlan, 1973", "B.M. Type Hym. 7.122”, "Alloxysta pleuralis (Cameron, 1879) q, M. Ferrer-Suay det. 2012” (white label).

\section{Paralectotype}

9, with the following labels: "Cameron 96-76", "Paralectotype" (round label with blue margins), "pleuralis det. N.D.M. Fergusson, 1984”, “Alloxysta pleuralis (Cameron, 1879) , M. Ferrer-Suay det. 2012" (white label). 


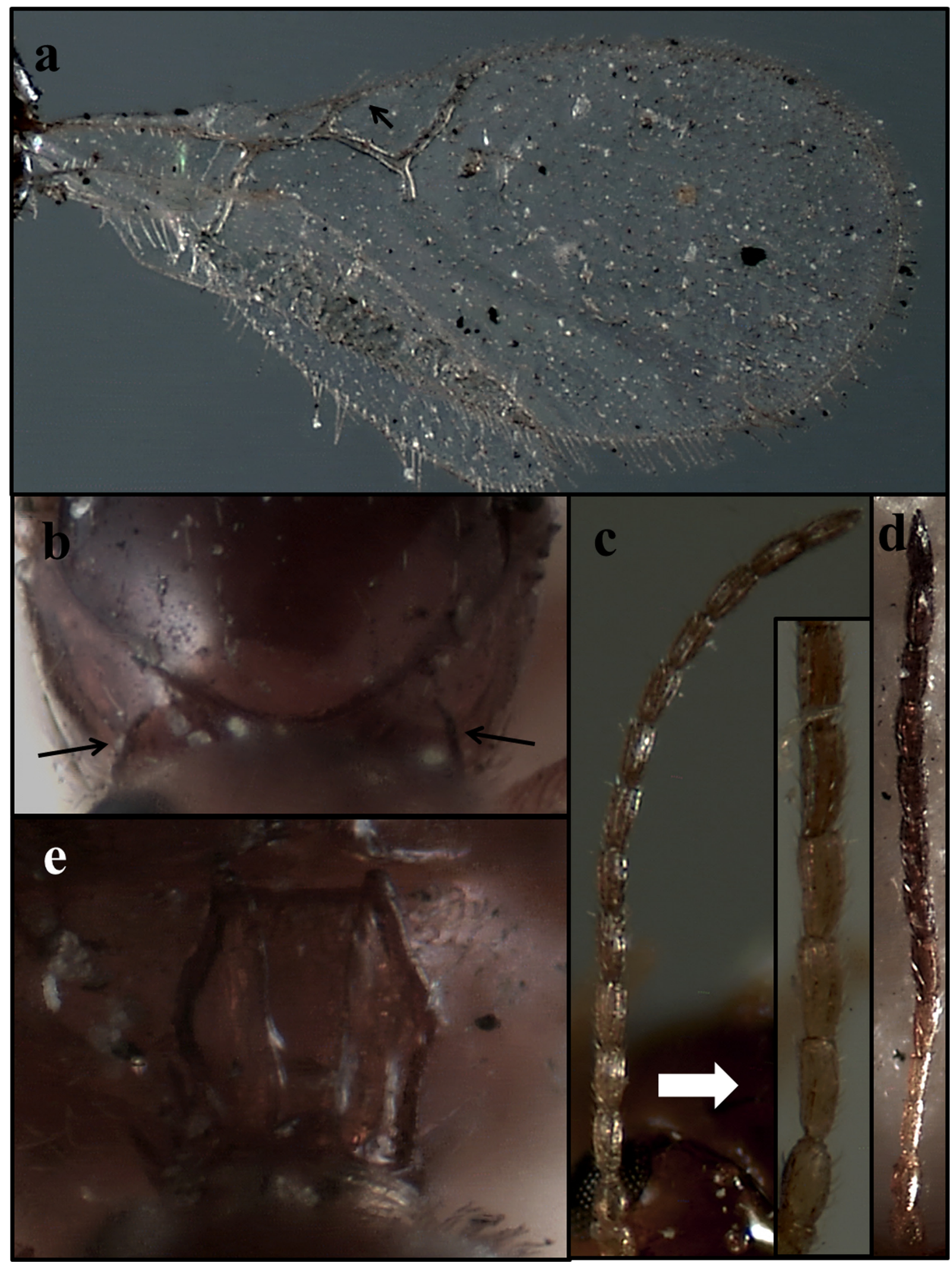

Fig. 6. Alloxysta pleuralis (Cameron, 1879). A. Fore wing. B. Pronotum (arrows indicate pronotal carinae). C. Antenna, ô. D. Antenna, ơ. E. Propodeum. 
Additional material

1 今, with the following labels: “”, "Oosterbeek, Netherlands, 11-8-1964, leg. Y. Noorlander", "aphid mummy on cultivated Cotoneaster Pendula", "Alloxysta pleuralis (Cameron) det. H.H. Evenhuis 1979".

\section{Redescription}

Coloration. Head dark yellow, mesosoma yellowish brown and metasoma dark brown. Scape, pedicel and F1-F3 dark yellow; F4-F12 brown. Legs and veins dark yellow.

HeAd. Transversely ovate, smooth and shiny, wider than high in front view. With setae below and between toruli and a few setae above toruli. With few or without setae on vertex and with many setae on face. Transfacial line $1.1 \mathrm{x}$ height of compound eye. Malar space $0.5 \mathrm{x}$ height of compound eye.

Antenna. Female: 13-segmented, filiform. All antennomeres covered with sparse setae. F1 and F2 thinner and smoother than remaining flagellomeres; F3-F11 club-shaped, with rhinaria. Pedicel $2.1 \mathrm{x}$ as long as wide; F1 $2.5 \mathrm{x}$ as long as wide; F2 $2.6 \mathrm{x}$ as long as wide; F3 $2.5 \mathrm{x}$ as long as wide; F4 2.4 $\mathrm{x}$ as long as wide. F1 subequal to pedicel; F1 $1.2 \mathrm{x}$ as long as F2; F3 1.2 $\mathrm{x}$ as long as F2; F4 1.1 $\mathrm{x}$ as long as F3; F4-F11 subequal in length, width and shape (Fig. 6D). Male: 14-segmented, filiform. All antennomeres covered with sparse setae. F1-F12 club-shaped, with rhinaria. F1-F3 slightly curved. Pedicel $1.7 \mathrm{x}$ as long as wide; F1 $2.0 \mathrm{x}$ as long as wide; F2 $2.3 \mathrm{x}$ as long as wide; F3 $1.9 \mathrm{x}$ as long as wide; F4 $2.0 \mathrm{x}$ as long as wide. F1 $1.3 \mathrm{x}$ as long as pedicel; F1-F12 subequal in length, width and shape (Fig. 6C).

Mesosoma. Pronotum covered with sparse setae, with two thick, clearly visible carinae (Fig. 6B). Mesoscutum smooth and shiny, round in dorsal view, with scattered setae. Scutellum smooth and shiny, with few scattered setae, abundant on apex of scutellum. Height of mesopleural triangle along anterior margin $1.3 \mathrm{x}$ height of mesopleuron. Propodeum covered by setae, with two well defined carinae reaching the base independently, thick and with curved sides (Fig. 6E).

FORE WING. Longer than body, $1.4 \mathrm{x}$ as long as mesosoma and metasoma together (Fig. 6A). Covered with dense pubescence; marginal setae present. Partially open radial cell, $2.1 \mathrm{x}$ as long as wide. R1 short and curved; Rs long and also curved (Fig. 6A).

Metasoma. Anterior part with an incomplete ring of setae, glabrous at centre, wider laterally. Metasoma smooth and shiny, T3 and T4 clearly distinguished.

\section{Remarks}

Alloxysta pleuralis is represented in BMNH by three specimens (females). However, in Cameron's original description five specimens were mentioned. The two other specimens were not found by Quinlan (1974: 9). Of the three remaining specimens, one was designated the lectotype and the other two were considered as paralectotypes by Quinlan (1974: 8). Alloxysta pleuralis is easily distinguished from other Alloxysta species by its combinations of features, especially the shape of the propodeal plate, which is unique for this species.

\section{Alloxysta semiaperta Fergusson, 1986}

Fig. 7

Alloxysta semiaperta Fergusson, 1986: 11.

\section{Type material}

\section{Holotype}

, with the following labels: "England: Oxon, 1.ix.1977, L.A. Mound Ex Epilobium", "Holotype" (round label with red margin), "Holotype of Alloxysta semiaperta det. N.D.M. Fergusson, 1984", "B.M. Type Hym. 7.174". 


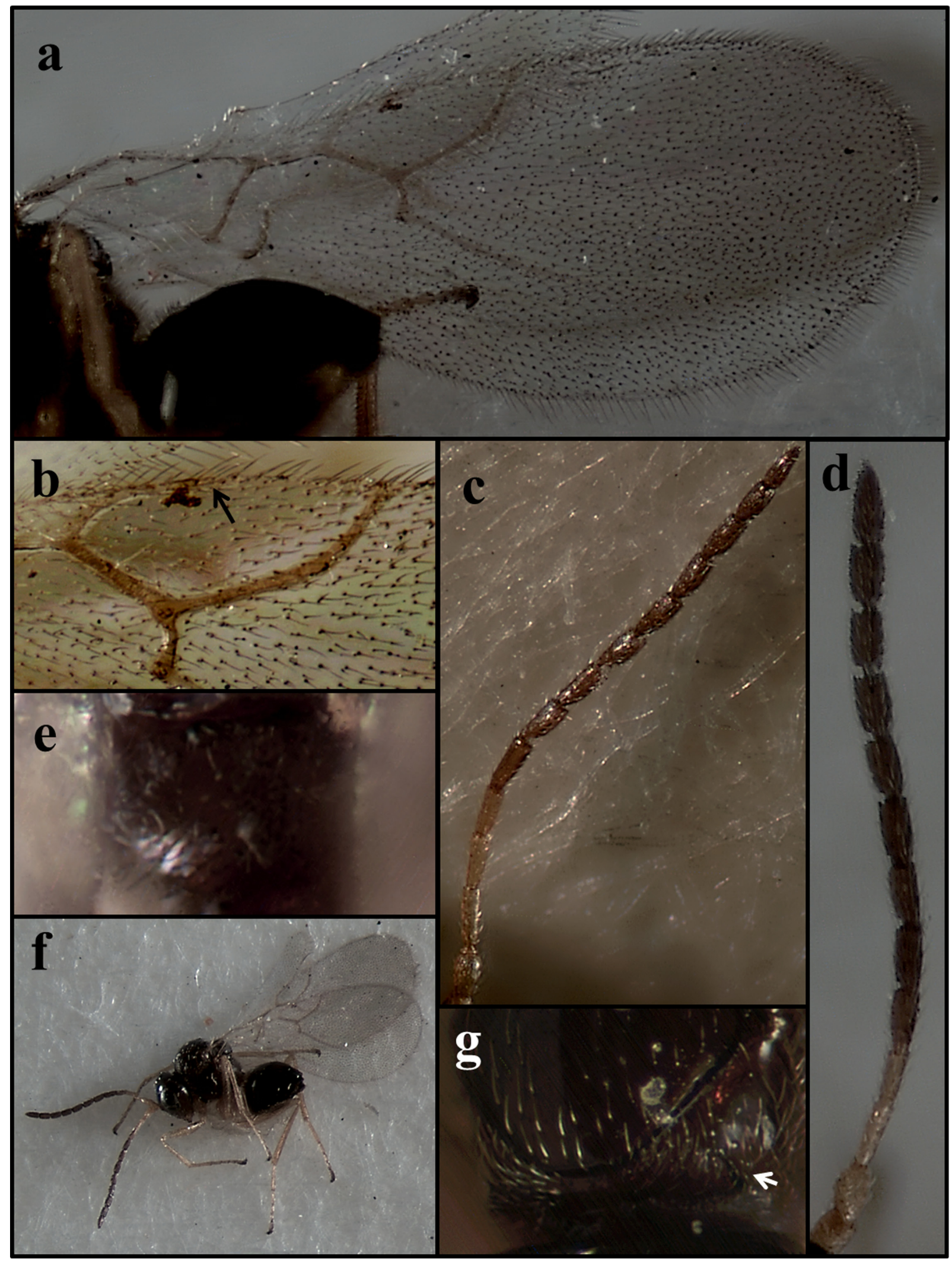

Fig. 7. Alloxysta semiaperta Fergusson, 1986. A. Fore wing. B. Fore wing radial cell (arrow indicates

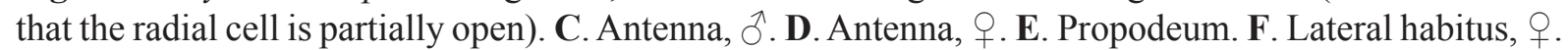
G. Pronotum (arrow indicates presence of pronotal carinae). 


\section{Paratype}

ô, with the following labels: "England: Oxon, 1.ix.1977, L.A. Mound, Ex. Epilobium" (handwritten), " స", "Paratype" (round label with yellow margin), "A. semiaperta det. N.D.M. Fergusson".

\section{Redescription}

Coloration. Head, mesosoma and metasoma dark brown. Scape, pedicel, F1 and F2 yellow; F3-F11 brown. Legs yellow and veins yellowish brown.

HEAD. Transversely ovate, smooth and shiny, wider than high in front view. With setae below, between and a few above toruli. Few setae on vertex and with many setae on face. Transfacial line $1.1 \mathrm{x}$ height of compound eye. Malar space $0.4 \mathrm{x}$ height of compound eye.

AnTENNA. Female: 13-segmented, filiform. All antennomeres covered with sparse setae. F1 and F2 thinner and smoother than remaining flagellomeres; F3-F11 club-shaped, with rhinaria. Pedicel $1.5 \mathrm{x}$ as long as wide; F1 $3.5 \mathrm{x}$ as long as wide; F2 $2.1 \mathrm{x}$ as long as wide; F3 $2.3 \mathrm{x}$ as long as wide; F4 $2.5 \mathrm{x}$ as long as wide. F1 $1.2 \mathrm{x}$ as long as pedicel; F1 $1.5 \mathrm{x}$ as long as F2; F3 $1.4 \mathrm{x}$ as long as F2; F4 $1.1 \mathrm{x}$ as long as F3; F4-F11 subequal in length, width and shape (Fig. 7D). Male: 14-segmented, filiform. All antennomeres covered with sparse setae. F1-F3 thinner and smoother than remaining flagellomeres; F4-F12 club-shaped, with rhinaria. Pedicel $1.7 \mathrm{x}$ as long as wide; F1 $2.9 \mathrm{x}$ as long as wide; F2 $3.1 \mathrm{x}$ as long as wide; F3 $2.5 \mathrm{x}$ as long as wide; F4 $2.9 \mathrm{x}$ as long as wide. F1 $1.1 \mathrm{x}$ as long as pedicel; F1 $1.1 \mathrm{x}$ as long as F2; F2 $1.1 \mathrm{x}$ as long as F3; F4 $1.1 \mathrm{x}$ as long as F3; F4-F12 subequal in length, width and shape (Fig. 7C).

Mesosoma. Pronotum covered with abundant setae, less setae on anterior margin, with two thick, clearly visible carinae (Fig. 7G). Mesoscutum smooth and shiny, round in dorsal view, with scattered setae. Scutellum also smooth and shiny, with few scattered setae, abundant on apex of scutellum. Height of mesopleural triangle along anterior margin $2.2 \mathrm{x}$ height of mesopleuron. Propodeum with many setae, without carinae (Fig. 7E).

ForE WING. Longer than body, $1.7 \mathrm{x}$ as long as mesosoma and metasoma together (Fig. 7A). Covered with dense pubescence; marginal setae present. Partially open radial cell, $2.7 \mathrm{x}$ as long as wide. R1 short and curved; Rs long and also curved (Fig. 7B).

Metasoma. Anterior part with an incomplete ring of setae, glabrous at centre, wider laterally. Metasoma smooth and shiny, T3 and T4 clearly distinguished.

\section{Remarks}

Alloxysta semiaperta is represented in BMNH by 7 males and 25 females. One female was designated by Fergusson as the holotype and the rest paratypes. This species is very similar to A. macrophadna (Hartig, 1941), because both have the radial cell partially open, pronotal carinae present and propodeal carina absent, but they differ in the proportions of the flagellomeres in both male and female: F2 shorter than F3 and F3 shorter than F4 in females of A. semiaperta (Fig. 4B), whereas F2 is longer than F3 and $\mathrm{F} 3$ subequal to $\mathrm{F} 4$ in females of $A$. macrophadna. Males of $A$. semiaperta have $\mathrm{F} 1$ longer than $\mathrm{F} 2$ and F3 shorter than F4, without any curved flagellomeres (Fig. 4C), whereas males of A. macrophadna have F1 subequal to F2 and F3 shorter than F4, F2 and F3 curved.

\section{Alloxysta victrix (Westwood, 1833)}

Allotria victrix Westwood, 1833: 495.

Allotria curvicornis Cameron, 1883: 366 (synonymized in Fergusson 1986: 11). 


\section{Type material}

\section{Holotype of Allotria curvicornis}

o, with the following labels: "Holotype" (round label with red margins), "Glen Lyon" (handwritten), "Cameron 96-73 Glen Lyon", "curvicornis Cam" (handwritten), "Allotria curvicornis Cameron" (handwritten), "Holotype Allotria curvicornis C. § det. J. Quinlan, 1977", "B.M. Type Hym. 7.168", “Alloxysta victrix (Westwood 1833) ठ̊ det. Ferrer-Suay, 2012" (white label).

\section{Remarks}

Alloxysta curvicornis is represented only by the holotype male at BMNH. This species was synonymized with $A$. victrix (Westwood, 1833) by Fergusson (1986: 11). The type material of this species has been revised and the validity of this synonymy is here confirmed.

\section{Conclusions}

Following this revision of the Cameron and Fergusson types deposited at the Natural History Museum, London, it was found that many of the synonymies established by Fergusson (1986: 10) were wrong. Within Alloxysta, Fergusson synonymized 10 of Cameron's nominal species under only three valid species. Seven species were synonymized with A. macrophadna after the revision of the type material; only $A$. filicornis remains as a valid synonymy, the other six species here being re-assigned as valid or as synonyms of other Cameron species. The synonymy of $A$. mullensis with $A$. brevis has been studied in detail within the revision of the "brevis group" (Ferrer-Suay et al. 2012d). According to these authors, A. mullensis is considered as valid species. Only two of the synonymies established by Fergusson are now considered valid (apart from A. filicornis synonymized with $A$. macrophadna): the synonymy of $A$. curvicornis with $A$. victrix and the synonymy of $A$. megaptera with $A$. castanea.

For these reasons, after this revision it is concluded that Fergusson (1986) does not reflect the actual diversity of Alloxysta in Great Britain. In addition to the species considered by Fergusson, there are 11 species previously reported from Great Britain by different authors: A. aperta (Hartig, 1841) by Andrews (1978: 78); A. circumscripta (Hartig, 1841) by Dalla Torre \& Kieffer (1910: 278) and Müller et al. (1999: 346); A. flavicornis (Hartig, 1841) by Dalla Torre \& Kieffer (1910: 282); A. fuscipes (Thomson, 1862) by Andrews (1978: 83); A. halterata (Thomson, 1862) by Hellén (1963: 2) and Müller et al. (1999: 346); A. leunisii (Hartig, 1841) by van Veen et al. (2003: 450); A. marshalliana (Kieffer, 1900) by Kieffer (1900: 114); A. pusilla (Kieffer, 1902) by Sanders \& van Veen (2010: 706); A. ramulifera (Thomson, 1862) by Andrews (1978: 86) and Müller et al. (1999: 346); A. tscheki (Giraud, 1860) by Cameron (1889: 54); and A. ullrichi (Giraud, 1860) by Cameron (1889: 56).

A key to identify the Alloxysta species present in Great Britain is given below. The type material of $A$. tscheki and A. ullrichi has not yet been studied, so they have been excluded from the key.

1 Brachypterous wings, wing not reaching further than the end of the metasoma .2

- Fully winged, longer than body length .5

2 Wings reaching the base of the metasoma; radial cell open .........A. marshalliana (Kieffer, 1900)

- Wings reaching the beginning of the metasoma; radial cell closed .3

3 Pronotal carinae present; propodeal carinae absent; male and some females brachypterous A. halterata (Thomson, 1862)

- Pronotal carinae absent; propodeal carinae present; males and females brachypterous .4 
4 Propodeal carinae present; F1 shorter than pedicel

A. brachyptera (Hartig, 1840)

- Propodeal carinae absent; F1 longer than pedicel A. pedestris (Curtis, 1838)

5 Radial cell closed (Fig. 8A)

- Radial cell open (Fig. 8B) or partially open (Fig. 8C) ............................................................16

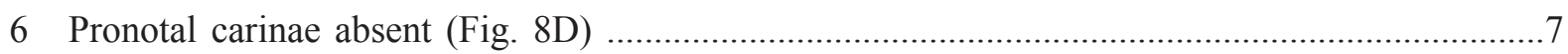

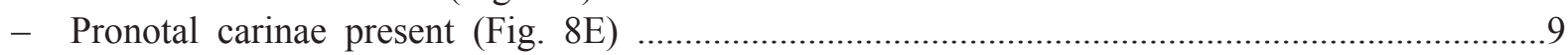

7 Propodeal carinae absent (Fig. 8F); F1 longer than pedicel, F1-F3 subequal in length

A. aperta (Hartig, 1841)

- Propodeal carinae present, defining a plate (Fig. 8G); F1-F3 otherwise

8 Antennae longer than body length; F1 subequal to pedicel, F1 longer than F2 and F2 subequal to F3 A. mullensis (Cameron, 1883)

- Antennae shorter than body length; F1 shorter than pedicel, F1-F3 subequal in length A. brevis (Thomson, 1862)

9 Propodeal carinae present, both forming a plate (Fig. 8G) ....................................................10

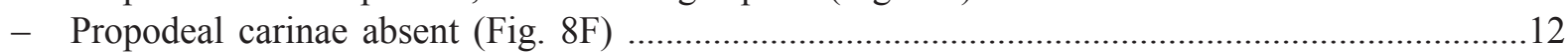

10 F1 subequal to pedicel; flagellomeres club-shaped and with rhinaria from F4; F1 longer than F2, F2 subequal to $\mathrm{F} 3$; radial cell $2.0 \mathrm{x}$ as long as wide .........A. ramulifera (Thomson, 1862)

- F1 longer than pedicel; flagellomeres club-shaped and with rhinaria from F3; proportions of flagellomeres otherwise; radial cell longer $(2.4-2.7 \mathrm{x}$ as long as wide) .........................11

11 Female: F2 shorter than F3; male: rhinaria begin in F1, pedicel-F3 subequal and slightly curved; propodeal plate with sides slightly curved; radial cell $2.7 \mathrm{x}$ as long as wide in female and $2.4 \mathrm{x}$ in male ............................................................. pusilla (Kieffer, 1902)

- Female: F2 subequal to F3; male: rhinaria begin in F2, pedicel-F3 not subequal, without any curved flagellomeres; propodeal plate with curved sides; radial cell $2.4 \mathrm{x}$ as long as wide in both male and female

A. flavicornis (Hartig, 1841)

12 Head lighter than mesosoma; F2-F4 subequal in length; radial cell $3.0 \mathrm{x}$ as long as wide; propodeum without setae in the medial area where the carinae are present in other species of Alloxysta (Fig. 8F) A. victrix (Westwood, 1833)

- Head same color as mesosoma; F2-F4 not subequal; radial cell shorter than $3.0 \mathrm{x}$ as long as wide (2.0-2.7 $\mathrm{x}$ as long as wide); propodeum entirely covered by setae

13 Flagellomeres from F3 club-shaped and with rhinaria; female with F1 subequal to F2, F2 shorter or subequal to F3; male with F1-F3 not subequal. Radial cell $2.5 \mathrm{x}$ as long as wide .... A. circumscripta (Hartig, 1841)

- Flagellomeres club-shaped and with rhinaria from another segment; different proportions between flagellomeres; radial cell longer or shorter than $2.5 \mathrm{x}$ as long as wide

14 Flagellomeres from F4 club-shaped and with rhinaria; F1 longer than pedicel, F1-F3 subequal in length; radial cell $2.4 \mathrm{x}$ as long as wide .........A. halterata (Thomson, 1862) (some $q$ q)

- Flagellomeres club-shaped and with rhinaria from another segment; F1 longer than F2; radial cell with different proportions 
15 Female: flagellomeres from F3 or F4 club-shaped and with rhinaria; F2 subequal to F3. Male: F1-F3 curved; radial cell $2.7 \mathrm{x}$ as long as wide ...............A. fuscicornis (Hartig, 1841)

- Female: flagellomeres from F2 club-shaped and with rhinaria; F2 shorter than F3. Male: F1 curved; radial cell $2.0 \mathrm{x}$ as long as wide A. leunisii (Hartig, 1841)

16 Radial cell partially open (Fig. 8B)

- Radial cell completely open (Fig. 8C)

17 Propodeal carinae present

- Propodeal carinae absent
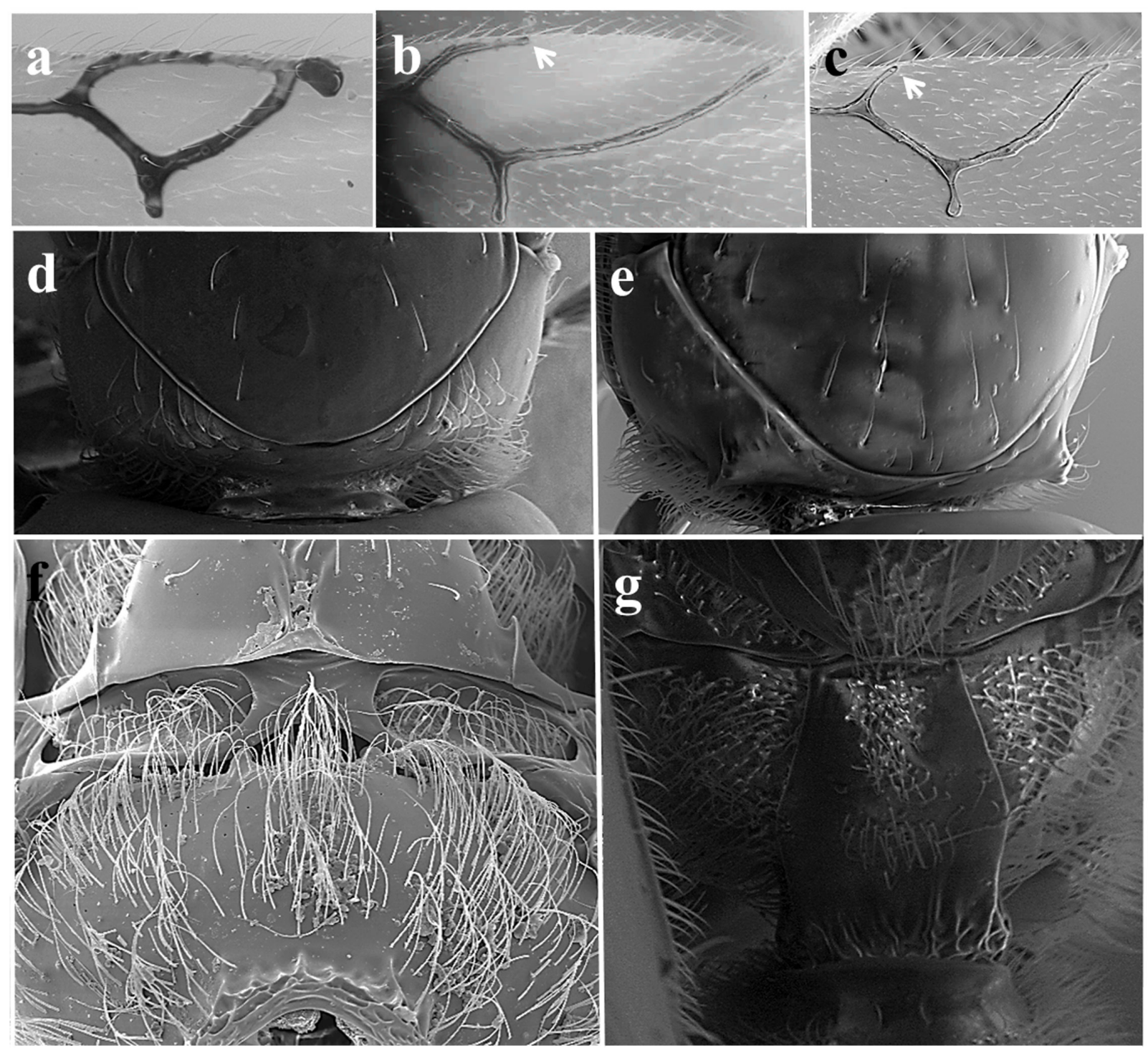

Fig. 8. General Charipinae features. A. Closed radial cell (Alloxysta brevis). B. Partially open radial cell (A. macrophadna). C. Open radial cell (A. medinae). D. Pronotal carinae absent (A. brevis). E. Pronotal carinae present (A. citripes). F. Propodeal carinae absent (A. victrix). G. Propodeal carinae present (A. castanea). 
18 Propodeum with two thick, well defined carinae, reaching the base independently and with sides curved and not plate-like; Rs almost straight; F1-F3 slightly curved in male

A. pleuralis (Cameron, 1879)

- Propodeum with two thin carinae, both forming a plate; Rs curved; F1-F3 not curved in male

19 Propodeal carinae forming a plate but not protruding; F1 subequal to pedicel; radial cell $2.1 \mathrm{x}$ as long as wide

A. citripes (Thomson, 1862)

- Propodeal carinae both forming a plate and protruding; F1 longer than pedicel; radial cell $2.3 \mathrm{x}$ as long as wide A. castanea (Hartig, 1841)

20 Female: F2-F4 not subequal in length. Male: F2 and F3 strongly curved; radial cell $3.0 \mathrm{x}$ as long as wide A. macrophadna (Hartig, 1841)

- Female: F2-F4 subequal in length. Male: without any curved flagellomeres; radial cell shorter than $3.0 \mathrm{x}$ as long as wide

21 Males and females: flagellomeres from F3 club-shaped and with rhinaria, F1 longer than F2 and radial cell $2.7 \mathrm{x}$ as long as wide A. semiaperta Fergusson, 1986

- Males and females: flagellomeres from F4 club-shaped and with rhinaria, F1 subequal or slightly shorter than F2 and radial cell longer ( $2.9 \mathrm{x}$ as long as wide) A. fuscipes (Thomson, 1862)

22 Propodeal carinae present (Fig. 8G)

- Propodeal carinae absent (Fig. 8F)

23 Female: F1 subequal to F2, F2 longer than F3 and F3 subequal to F4. Male: flagellomeres from F2 club-shaped and with rhinaria, F2 curved; propodeal carinae joined, forming a plate; radial cell $2.2 \mathrm{x}$ as long as wide A. abdera Fergusson, 1986

- Female: F2-F4 subequal in length. Male: flagellomeres from F1 club-shaped and with rhinaria; propodeal carinae thin and well defined at the top and joined at the bottom; radial cell 2.6 $\mathrm{x}$ as long as wide A. pallidicornis (Curtis, 1838)

24 F1 subequal to F2, F2 longer than F3; radial cell $3.0 \mathrm{x}$ as long as wide

A. basimacula (Cameron, 1886)

- F1 longer than F2, F2 subequal to or shorter than F3; radial cell shorter than $3.0 \mathrm{x}$ as long as wide

25 F2-F4 subequal in length; R1 reaching costal margin A. crassa (Cameron, 1889)

- F2 shorter than F3, F3 subequal to F4; R1 not reaching costal margin

A. piceomaculata (Cameron, 1883)

\section{Acknowledgements}

This research was supported by the projects CGL2008-00180 and CGL2011-22889 of the Ministerio de Ciencia e Innovación (Spain) and through grant AP2009-4833 from the Ministerio de Educación (Spain). This research received support from the SYNTHESYS Project, http://www.synthesys.info/, which is financed by the European Community Research Infrastructure Action under the FP7 Integrating Activities Programme.

\section{References}

Andrews F.G. 1978. Taxonomy and host specificity of Nearctic Alloxystinae with a catalogue of the World species (Hymenoptera: Cynipidae). Occasional Papers in Entomology 25: 1-128. 
Cameron P. 1879. On some new or little known British Hymenoptera. Transactions of the Entomological Society of London 1879: 107-119. http://www.biodiversitylibrary.org/item/48188\#page/137/mode/1up

Cameron P. 1883. Descriptions of sixteen new species of parasitic Cynipidae, chiefly from Scotland. Transactions of the Royal Entomological Society of London 16 (4): 365-374. http://dx.doi. org/10.1111/j.1365-2311.1883.tb02952.x

Cameron P. 1886. The fauna of Scotland, with special reference to Clydesdale and the Western District. Proccedings of the Natural History Society of Glasgow 3: 53-95.

Cameron P. 1888. On some new or little known British parasitic Cynipidae. Entomologist's Monthly Magazine 24: 209-211. http://www.biodiversitylibrary.org/item/106468\#page/219/mode/1up

Cameron P. 1889. On the British species of Allotrinae, with descriptions of other new species of parasitic Cynipidae. Memoirs of the Manchester Literary and Philosophical Society 2: 53-69.

Curtis J. 1838. British Entomology; being Illustrations and Descriptions of the Genera of Insects found in Great Britain and Ireland: Containing Coloured Figures of Naturae of the most Rare, and Beautiful Species and in many Instances of the Plants upon which they are Found. Vol. 15: 674-721. Privately published, London.

Dalla Torre K.W. \& Kieffer J.J. 1902. Cynipidae. In: Wytsman P. (ed.) Genera Insectorum. Vol. I: 1-84. Verteneuil \& Desmet, Brussels.

Dalla Torre K.W. \& Kieffer J.J. 1910. Cynipidae. Das Tierreich XXIV. R. Friedlander \& Sons, Berlin. $891 \mathrm{pp}$.

Evenhuis H.H. 1972. Studies on Cynipidae Alloxystinae. 2. The identity of some species associated with aphids of economic importance. Entomologische Berichten 32: 210-217.

Evenhuis H.H. 1982. A study of Hartig's Xystus species with type designations and new synonyms (Hymenoptera: Cynipidae Alloxystinae and Charipinae). Spixiana 5: 19-29. http://www.biodiversity library.org/item/89565\#page/27/mode/1up

Fergusson N.D.M. 1986. Charipidae, Ibaliidae and Figitidae (Hymenoptera: Cynipoidea). Handbooks for the Identification of British Insects 8 (1c): 1-55.

Ferrer-Suay M., Paretas-Martínez J., Selfa J. \& Pujade-Villar J. 2012a. Taxonomic and synonymic World catalogue of the Charipinae and notes about this subfamily (Hymenoptera: Cynipoidea: Figitidae). Zootaxa 3376: 1-92.

Ferrer-Suay M., Selfa J. \& Pujade-Villar J. 2012b. Revision of V.I. Belizin's type material of Alloxysta (Hymenoptera: Figitidae: Charipinae) deposited in the Zoological Institute of the Russian Academy of Sciences. Zoosystematica Rossica 21 (2): 279-290.

Ferrer-Suay M., Selfa J., \& Pujade-Villar J. 2012c. Revision of the Ionescu collection related to Charipinae subfamily (Hymenoptera: Figitidae) deposited in the "Grigore Antipa" National Museum of Natural History (Bucharest). Travaux du Muséum National d'Histoire Naturelle "Grigore Antipa" 55 (2): 277-284. http://dx.doi.org/10.2478/v10191-012-0017-7

Ferrer-Suay M., Selfa J. \& Pujade-Villar J. 2012d. Taxonomic revision of the Alloxysta brevis group (Hymenoptera, Cynipoidea, Figitidae, Charipinae). Boletín de la Sociedad Aragonesa de Entomología 51: $237-249$.

Ferrer-Suay M., Selfa J. \& Pujade-Villar J. 2013. Revision of Thomson and Zetterstedt collections of Alloxysta genus deposited in Lund Museum of Zoology (Sweden). Entomologisk Tidskrift 134: 77-102. 
Giraud J. 1860. Enumeration des Figitides de l'Autriche. Verhandlungen der Kaiserlich-Königlichen Zoologisch-Botanischen Gesellschaft in Wien 10: 123-176. http://www.biodiversitylibrary.org/ item/86010\#page/287/mode/1up

Hafez M. 1961. Seasonal Fluctuations of Population Density of the Cabbage Aphid, Brevicoryne brassicae (L.), in the Netherlands, and the Role of its Parasite, Aphidius (Diaeretiella) rapae (Curtis). Tijdschrift Over Plantenziekten 67 (5): 345-548. http://dx.doi.org/10.1007/BF02089167

Hartig T. 1840. Ueber die Familie der Gallwespen. Zeitschrift für Entomologie 2: 176-210.

Hartig T. 1841. Erster Nachtrag zur Naturgeschichte der Gallwespen. Zeitschrift für Entomologie 3: 322-358.

Hellén W. 1931. Zur Kenntnis der Cynipiden-Fauna Islands. Göteborgs Kungliga Vetenskaps- och Vitterhetssamhälles Handlingar 2 (5): 1-8.

Hellén W. 1963. Die Alloxystininen Finnlands (Hymenoptera: Cynipidae). Fauna Fennica 15: 1-23.

Kieffer J.J. 1900. Ueber Allotrinen. Wiener Entomologische Zeitung 19: 112-115.

Kieffer J.J. 1902. Description de quelques Cynipides nouveaux ou peu connus et de deux de leurs parasites (Hyménoptères). Bulletin de la Société d'Histoire Naturelle de Metz 22: 1-18. http://www. biodiversitylibrary.org/item/105303\#page/11/mode/1up

Kieffer J.J. 1904. Description de quelques Cynipides exotiques dont l'un forme un genre nouveau. Bulletin de la Société d'Histoire Naturelle de Metz 23: 59-66. http://www.biodiversitylibrary.org/ item/105163\#page/71/mode/1up

Müller C.B., Adriaanse I.C.T., Belshaw R. \& Godfray H.C.J. 1999. The structure of an aphidparasitoid community. Journal of Animal Ecology 68: 346-370. http://dx.doi.org/10.1046/j.1365$\underline{2656.1999 .00288 . x}$

Paretas-Martínez J., Arnedo M.A., Melika G., Selfa J., Seco-Fernández M.V., Fülöp D. \& Pujade-Villar J. 2007. Phylogeny of the parasitic wasp subfamily Charipinae (Hymenoptera, Cynipoidea, Figitidae). Zoologica Scripta 36: 153-172. http://dx.doi.org/10.1111/j.1463-6409.2006.00269.x

Pujade-Villar J., Ferrer-Suay M., Selfa J. \& Alonso-Zarazaga M.A. 2011. What is Alloxysta fulviceps (Curtis, 1838) (Hymenoptera: Cynipoidea: Figitidae: Charipinae)? Memoirs of Museum Victoria 68: 67-70.

Quinlan J. 1974. The British Cynipoidea (Hymenoptera) described by P. Cameron. Bulletin of the Natural History Museum, Entomology Series 31 (1): 1-21.

Quinlan J. 1978. On the identity of some British Alloxystinae described by P. Cameron and by J.J. Kieffer (Hymenoptera, Cynipidae). Entomologische Berichten 38: 71-74.

Sanders D. \& van Veen F.J.F. 2010. The impact of an ant-aphid mutualism on the functional composition of the secondary parasitoid community. Ecological Entomology 35 (6): 704-710. http://dx.doi. org/10.1111/j.1365-2311.2010.01230.x

Thomson C.G. 1862. Försök till uppställning och beskrifning af Sveriges Figiter. Öfversigt af Kongliga Svenska Vetenskaps-Akademiens Förhandlingar 18: 395-420. http://www.biodiversitylibrary.org/ item/52760\#page/413/mode/1up

Van Veen F.J., Belshaw R. \& Godfray H.C.J. 2003. The value of the ITS2 region for the identification of species boundaries between Alloxysta hyperparasitoids (Hymenoptera: Charipidae) of aphids. European Journal of Entomology 100: 449-453. http://www.biodiversitylibrary.org/item/52760\#page/413/ mode/1up 
Westwood J.O. 1833. Notice of the habits of a Cynipidous insect parasitic upon the Aphis rosae with descriptions of several other parasitic Hymenoptera. Magazine of Natural History 6: 491-497. http:// www.biodiversitylibrary.org/item/19636\#page/505/mode/1up

Manuscript received: 23 January 2013

Manuscript accepted: 17 May 2013

Published on: 16 August 2013

Topic editor: Koen Martens

Desk editor: Danny Eibye-Jacobsen

Printed versions of all papers are also deposited in the libraries of the institutes that are members of the EJT consortium: Muséum National d'Histoire Naturelle, Paris, France; National Botanic Garden of Belgium, Meise, Belgium; Royal Museum for Central Africa, Tervuren, Belgium; National History Museum, London, United Kingdom; Royal Belgian Institute of Natural Sciences, Brussels, Belgium; Natural History Museum of Denmark, Copenhagen, Denmark. 